\title{
Comparison of MARC Serials, NSDP, and ISBD-S
}

Josephine S. PULSIFER: MARC Development Office, Library of Congress,
Washington, D.C.

Editor's note: The discrepancies and variations described in this document are being examined by an Ad Hoc Serials Discussion Group, and are being resolved by the staffs of the Library of Congress and the National Serials Data Program. Readers are referred to the discussions of Richard Anable and Audrey Grosch, in this issue.

Briefly characterizes and compares the specifications for serial records of the MARC Serials Distribution Service, the National Serials Data Program, and the International Standard Bibliographic Description for Serials. Both data content and, where applicable, machine format are analyzed.

\section{INTRODUCTION}

That current interest in machine-readable serial records is running high is evidenced by the recent establishment of the Ad Hoc Serials Discussion Group, the questionnaire from the ARL Ad Hoc Committee on MachineBased Serial Records, and various union lists of serials projects. There is recognition of the inability of libraries to support unilateral conversion of serial records to machine-readable form and of the undesirability of creating uncoordinated data bases which are compatible neither in bibliographic data nor machine format.

\section{NEW DEVELOPMENTS}

Three recent developments, while all directed towards standardization, are nevertheless adding to the confusion of those libraries which, singly or in groups, are attempting to determine how best to acquire the required serials data base.

These three developments are: (1) the MARC Serials Distribution Service (MARC-S); (2) the International Standard Bibliographic Description for Serials (ISBD-S); and (3) the National Serials Data Program (NSDP). Each of these efforts has a somewhat different goal, operates within different constraints, and is to some degree in conflict with the other two. 


\section{MARC Serials Distribution Service}

The MARC Distribution Service distributes machine-readable records for all Library of Congress (LC) serials in roman alphabet languages given printed card cataloging since February 1, 1973. Romanized records for serials in nonroman alphabets will be added in the fall of 1973. Records for recataloged serials are also included. The goal of MARC-S is the creation of multipurpose machine-readable serial records, with standard catalog data in the MARC serials format, for LC's own data base and for dissemination to libraries and related communities. ${ }^{1}$ These records follow the Anglo-American Cataloging Rules (AACR), with superimposition of entries established under earlier rules. ${ }^{2}$ Consideration is being given to abandonment of superimposition. Approximately 3,000 serial titles in LC's Main Reading Room and Science Reading Room collections have been converted to MARC and will be made available for distribution as soon as possible. Expansion of the service to a phased conversion of records for retrospective but active titles would be most desirable, beginning with some identifiable and widely useful subset. Expansion would require both space and funds and a determination of priorities between automation of New Serial Titles and progress towards a comprehensive data base for LC current serial receipts.

\section{National Serials Data Program}

The NSDP is the United States national center of UNISIST's International Serials Data System (ISDS), which has sole responsibility for controlling the assignment of the International Standard Serial Number (ISSN). To NSDP is delegated responsibility for the assignment of the ISSN to serials published in the United States. Serials published outside the U.S. are assigned by the appropriate national center or by the international center in Paris.

Besides its ISDS responsibility, NSDP has as a prime objective the provision of a data base of serial publications for the three national libraries (Library of Congress, National Agricultural Library, and National Library of Medicine). The program is aimed to be of benefit to the national user community, including libraries, subscription agencies, publishers, and abstracting and indexing services.

As set forth in the ISDS guidelines, ISDS centers will develop and maintain national registers of serial publications, containing all the necessary information for the identification of the serials. The international center is to distribute a printed register (in ISSN and title sequences) as well as a machine file of all titles, including a regular supplement. NSDP plans to publish similar registers containing a subset of the international register.

- The information on ISDS and NSDP has been taken from the following publications: (1) ISDS Guidelines-NSDP copy. (Received April 16, 1973.) (2) National Serial Data Program, "Notes on Special Development in the Program," No. 2, January 1973 [p. 1]. 
NSDP must follow the ISDS guidelines in providing to the international center a set of data elements considered essential for identification of the serial. Certain other elements are defined as optional ISDS elements. NSDP has defined certain additional elements as needed for the national record. International Standards Organization (ISO) standards must be followed where applicable.

\section{International Standard Bibliographic Description for Serials}

The ISBD-S defines the elements necessary for the identification of serials, assigns an order to these elements in the entry, and specifies the punctuation designating these elements. ${ }^{8}$ The ISBD-S, as a descriptive catalog record only, is not concerned with access points to the record (i.e., entries). It is not a machine format, though its standard order of elements and standard punctuation greatly assist the machine identification (i.e., format recognition) of the various elements. The work of the Working Group on the International Bibliographic Description for Serials of the International Federation of Library Associations has been completed and will soon be published. This document will be subject to revision following a period of study and/or use by IFLA member organizations. The ISBD-S will be put into practice by LC when it is accepted by the American Library Association and incorporated into the Anglo-American Cataloging Rules.

\section{COMPARISON OF DATA CONTENT: MARC-S, NSDP, and ISBD-S}

\section{Entry}

MARC-S: LC practice in choice of entry (author/title vs. title) based on AACR $6 \mathrm{~A}-6 \mathrm{C}$, is followed. The form of entry is that used by the $\mathrm{Li}$ brary of Congress, i.e., AACR with superimposition. When main entry is under author, the author is usually omitted from the title field.

NSDP: The ISDS includes no name entry, main or added, in its essential or additional data elements. Names are included in the key title under certain circumstances. However, NSDP has added "Author Entries" as an essential national data element, along with a means of indicating the AACR main entry. These author entries are established by NSDP following AACR form of entry without superimposition, and an authority file is maintained to relate variant forms of entry used by the national libraries to the NSDP form.

ISBD-S: ISBD-S (like ISBD-M) is not concerned with entry. It does not preclude main or added entries, but provides a description that does not depend on entry for identification. An author statement follows the title, unless the author is part of the distinctive title or there is no author.

\section{Title and Statement of Authorship}

MARC-S: The title is transcribed from the title page according to AACR. Subtitles are omitted unless necessary for the identification of the publication. The author statement is omitted when the author appears in 
substantially the same form in the main entry or when there is no author. The MARC format provides an additional field for "Title as It Appears on the Piece," but this field is not included in MARC-S records at the present time.

NSDP: The key title is the title as it appears on the piece. It may include the issuing body when the name is grammatically, typographically, or visually linked to the rest of the title or when it is needed to make a generic title distinctive. In addition, it may be modified by place and/or date of publication to make it unique.

NSDP assigns a new ISSN and creates a new record when the wording of the key title changes." "Minor" changes, including prepositions and spelling changes that may significantly change filing, do not result in a new record or ISSN. Where the author or issuing body changes, no new record is created unless the author is part of the key title. Because a new record means a new key title and new ISSN, the determination as to whether a title change is to result in a new record may only be made by the official ISDS agency. When the author statement is not grammatically linked to the title and the title is a "generic" term, the author statement is added to the title but separated from it by a dash. The interpretation of generic is limited, according to the ISDS guidelines, to terms denoting the kind and/ or periodicity of a publication. ${ }^{4}$

A study of the differences in practice between LC and NSDP with respect to creating new records for change of title is attached.

ISBD-S: The ISBD-S "distinctive" title is essentially the same as the NSDP key title with the important differences that it need not be unique, and that it is always followed by an author statement unless the author is part of the distinctive title or there is no author. Therefore, there is no requirement for centralized determination of the distinctive title. This determination can be performed by any library or any other organization by applying the ISBD-S rules.

This paper does not attempt to point out all the differences among the three systems. It may be noted, however, that there are differences in the romanization schemes used by LC and NSDP, since NSDP uses ISO romanization tables and LC uses ALA romanization tables.** NSDP also uses the country code being developed under ISO while MARC-S uses the country codes approved by the three national libraries. However, it is likely that when the ISO code becomes a standard, it may be adopted for MARC-S.

\section{REFERENCES}

1. Library of Congress. MARC Development Office. Serials: A MARC Format. 2d. ed. Washington, 1973. In press.

$\cdots$ This assumes that NSDP is notified of all changes by the publisher or a user; otherwise it will not know that there is a change to be considered.

$\cdots$ ISBD-S is not concerned with romanization. 
2. Anglo-American Cataloging Rules. North American Text. Chicago: American Library Association, 1967.

3. International Federation of Library Associations. I.S.B.D.(S); International Standard Bibliographic Description for Serials. [4th (?) document] Paris [Oct. 1972-Jan. 1973] 2 pts.

4. UNISIST International Serials Data System. Guidelines for ISDS. Paris: May 1973, 58 p. + Appendixes.

\section{APPENDIX 1}

Examples of Successive Title Entries vs. Use of a Variant Title Note (or Equivalent) by LC Serial Record and NSDP.

Perusal of the records for serials in the Main Reading Room Collection points up certain practices that are operative in Serial Record (SR) Cataloging Section with respect to making new entries for change of title. These practices do not necessarily correspond with NSDP's practice, based on ISDS guidelines, in assigning new key titles.

The basic rule that a change in the wording of a title results in a new record is applicable to both operations. The difference comes in the exceptions to the basic rule. NSDP assigns a new key title when nouns or adjectives are added, changed, or deleted, based almost entirely on the difference in the words. It does not change key title when only a preposition or a conjunction is changed, nor when the change affects only a subtitle. NSDP appears to prefer a less strict interpretation of the change of wording rule prescribed by ISDS. SR, while making a new entry for "major" wording changes, tends to retain the old entry (adding a title varies note) in more cases. A change in scope appears to be a more significant factor than the wording. Where no change in scope is involved, the determination to change is made on the basis of how closely the two entries would file. If change in scope is not involved, subtitle changes do not generate a new entry.

Examples

NSDP would make new key title?

(a) SR changes because of changes in scope

From: Annuaire statistique de la Belgique et du Congo Belge yes

To: Annuaire statistique de la Belgique

From: The Boarding school directory of the United States yes

To: The Boarding school directory of the United States and Canada

From: Commercial television, cinema, and radio directory

To: Commercial television year book

From: Braby's commercial directory of South and Central Africa yes

To: Braby's commercial directory of South East and Central Africa

From: Brown's directory of American gas companies.

Gas statistics

yes

To: Brown's directory of North American gas companies

- According to consultation with Mary Sauer, National Serials Data Program. 
NSDP would make new key title?

(b) SR makes new entry on the basis of filing arrangement.

From: Adressbuch der Haupstadt Hannover

yes

To: Adressbuch der Landeshauptstadt Hannover

From: American Marketing Association. National membership roster

To: American Marketing Association. Membership roster

yes

From: California. Secretary of State. Roster of state, county, city ...

To: California. Secretary of State. Roster of federal, state, county

From: Cape Times South African directory

To: Cape Times directory of Southern Africa

From: Annuaire fructidor

To: Annuaire international fructidor

From: Best's recommended adjusters and investigators

To: Best's recommended insurance adjusters

From: Personalities in the Caribbean

To: Personalities Caribbean

(c) SR does not make new entry

From: American Chamber of Commerce in France. Directory of American business in France

To: American Chamber of Commerce in France. Directory

From: Canadian Newspaper Service, ltd. National reference book on Canadian business personalities . . .

To: Canadian Newspaper Service, ltd. National reference book

From: High school track and field annual

To: High school track

From: U.S. Civil Aeronautics Board. Handbook of airline statistics, United States certificated air carriers

To: U.S. Civil Aeronautics Board. Handbook of airline statistics

From: Who's who, Jamaica, British West Indies

To: Who's who Jamaica

From: Child Welfare League of America. Directory of member agencies

To: Child Welfare League of America. Directory of member agencies and associates

From: Ports, dues, charges, and accommodations throughout the world

To: Ports, dues, charges, and accommodations

From: Rotary International. The official directory

To: Rotary International. Official directory of Rotary International

From: Guia Lascano del comercio y de la industria, profesionales y elementes oficial del Peru

- NSDP, following ISDS guidelines, would not change key title, but is not in agreement.

- NSDP would append main entry to the new key title in this instance.

$\uparrow$ NSDP, following ISDS guidelines, would assign a new key title, but is not in agreement.

¥ Considered a subtitle by NSDP. 
NSDP would make new key title?

To: Guia Lascano del Peru

From: Marine catalog and buyers' directory

yes $^{*}$

To: Marine catalog buyers' guide

From: The Mobile home dealers of the United States and Canada

yes

To: Mobile homes and recreational vehicle dealers of the United States and Canada

From: National Federation of Settlements and Neighborhood Centers. Directory of member houses

To: National Federation of Settlements and Neighborhood Centers. Directory of member agencies

From: California. Legislature. List of members, officers, committees, and rules of the two Houses

To: California. Legislature. List of Senate and Assembly members, officers, attaches, committees

From: Turner, Clarence A. Financial statistics, public utilities

To: Turner, Clarence A. Financial statistics of public utilities

From: Instituto Nacional del Libro Español. Guía de editores y libreros

To: Instituto Nacional del Libro Español. Guía de editores y de libreros de España

From: International Telecommunication Union. General Secretariat. Official list of telegraph offices opened for international traffic

To: International Telecommunication Union. General Secretariat. Official list of telegraph offices open for international service

From: List of doctoral dissertations in history now in progress at universities in the U.S.

To: List of doctoral dissertations in history in progress ...

SR makes new record when main entry changes, or when new title merits entry under title main entry.

From: Architects Registration Council of the United Kingdom. Register of registered architects ... .

To: The Register of architects (title main entry)

From: American Automobile Association North Central tour book

To: North central states. (title main entry)

From: American Gas Association. Gas facts

To: American Gas Association. Dept. of Statistics. Gas facts

From: American Nurses' Association. Nursing Information Bureau. Facts about Nursing

To: American Nurses' Association. Facts about Nursing

From: Illinois University. Dept. of Agricultural Economics. Aerr

To: Illinois University at Urbana-Champaign. Dept. of Agricultural Economics, Aerr

\footnotetext{
- NSDP, following ISDS guidelines, would assign a new key title, but is not in agreement.
}

$\dagger$ NSDP considers this a minor change, assuming main entry is part of key title. 
NSDP would make new key title?

From: Compagnie internationale des wagons-lits et des grands expres européens. Guide

yes

To: Compagnie internationale des wagons-lits et du tourism. Guide

(e) SR makes a new record when an initialism or name is appended at the beginning of the title.

From: Arena, auditorium, stadium guide

To: AASG; arena, auditorium, stadium guide

From: American Association of State Highway Officials.

Reference book

To: American Association of State Highway Officials. AASHO reference book of member department personnel and committees

From: American Concrete Institute. Directory

To: American Concrete Institute, ACI directory

From: Belgium and Luxembourg

yes

To: Fodor's Belgium and Luxembourg

From: Adressbuch von Burgenland für Industrie, Handel, Gewerbe

To: Herald Adressbuch von Burgenland für ... .

From: Christian Booksellers Association. Suppliers directory for Christian booksellers

To: Christian Booksellers Association. CBA suppliers directory

From: Classic Car Club of America. Directory

To: Classic Car Club America. Handbook and directory $1964-$ 